\title{
Effect of Tropical Legumes on Soil Nutrient Dynamics and its Consequence on Rice Production
}

\author{
Y. M. Ramesha ${ }^{1^{*}}$, Manjunatha Bhanuvally ${ }^{2}$, Ashok Kumar Gaddi ${ }^{2}$, S. A. Biradar ${ }^{1}$ \\ and M. R. Umesh ${ }^{1}$ \\ ${ }^{1}$ Department of Agronomy, University of Agricultural Sciences, Raichur-584 102, Karnataka, India. \\ ${ }^{2}$ Department of Soil Science and Agricultural Chemistry, University of Agricultural Sciences,
} Raichur-584 102, Karnataka, India.

\begin{abstract}
Authors' contributions
This work was carried out in collaboration between all authors. Author YMR designed the study, performed the statistical analysis, wrote the protocol and wrote the first draft of the manuscript. Authors MB and AKG managed the analyses of the study. Author AKG managed the literature searches. All authors read and approved the final manuscript.
\end{abstract}

Article Information

DOI: $10.9734 /$ IJPSS/2017/32514

Editor(s):

(1) Susana Rodriguez-Couto, Unit of Environmental Engineering, Paseo Manuel Lardizabal, Donostia-San Sebastián, Spain.

Reviewers:

(1) Nirmali Gogoi, Tezpur Central University, Assam, India.

(2) Samson Manono Makone, Kisii University, Kenya.

Complete Peer review History: http://www.sciencedomain.org/review-history/18990

Original Research Article

Received $28^{\text {th }}$ February 2017 Accepted $23^{\text {rd }}$ March 2017

Published $9^{\text {th }}$ May 2017

\section{ABSTRACT}

Background and Scope: In Tungabhadra command area of Karnataka, India, soil productivity and yield of crops is declining year after year due to continues flood irrigation for rice and farmers are practicing only mono-cropping (rice-rice) so that possibility of accumulation of salts in the soil leads to salinity and reduction in the soil productivity. To overcome these problems, we hypothesized that growing tropical legumes in paddy fallow during summer and incorporation of these tropical legumes in to soil to improve the soil productivity therefore improving the soil nutrient dynamics and conserve soil organic carbon content that would result in higher grain yield of rice.

Conclusion: Overall, the soil nutrient status was improved and increased the yield of succeeding crop rice when incorporating the tropical legumes in to soil. Our results suggested that, growing leguminous plants during summer in paddy fallow and incorporated after two months, this improved the soil nutrient status and offcourse, increases the yield of succeeding crop of rice. 
Keywords: Tropical legumes; incorporation; DSR; uptake of nutrients.

\section{ABBREVIATIONS}

DSR : Direct seeded rice

$D A S$ : Days after sowing

$D A I$ : Days after incorporation

DAP : Diamonium Phosphate

MOP : Muriate of potash

RDF : Recommended dose of fertilizer

\section{INTRODUCTION}

Tropical legumes which are used as bio-fertilizer, plants and their parts (stem, leaves, twigs or roots) that are used into the soil by incorporating them or without any incorporation to improve soil health by adding nutrients contained in them and hence increasing to content of plant nutrients of soil with an goal of obtaining increased crop productivity and crop yields. There are wide range of tropical legumes, some are cultivated and some wildly grown in nature. Some tropical legumes develop nodules in stem, in roots and in some both. Nodule forming green manuring crops contains Rhizobium bacteria which has the ability to fixing of atmospheric nitrogen and produces $\mathrm{N}$ for the crop itself and to the soil. Other leguminous plants which are grown but rich in nutrient content such as cowpea, field bean, blackgram, cluster bean, horsegram, pillepiesru etc., also can supply plant nutrients after incorporation into the soil.

Rice (Oryza sativa L.) is the most important cereal crop in Asia, grown under varying hydrological conditions. It is the principal source of food for more than half of the world population [1], especially in South and Southeast Asia, Latin America and Indonesia. In India, it is a dominating staple food crop of fertile and alluvial soils of north west India, particularly IndoGangetic plains [2]. It occupies 36.95 million hectares with a total production of 80.41 million tonnes of rice. Its cultivation is mainly practised through transplanting which is cumbersome and labour intensive. This technique requires puddling and continuous ponding of water for first 15 days for establishment of the seedlings. It leads to nutrient losses through leaching besides causing high evapotranspirational losses during hot summer. Therefore, of late, need has acutely been felt to develop technically viable and economically feasible alternate technique for growing paddy in this area. In this context direct seeded rice (DSR) provides an option. It saves labour and water and make paddy cultivation cost effective. It matures earlier (7-10 days) than the transplanted crop due to the absence of transplanting shock [3] and allows timely planting of succeeding crop. It also ensures the timely sowing in a stipulated time frame. Direct seeded rice accounts for 35 per cent of the total rice cultivated area in India [4]. Nutrient management methods are the major factor that determines the productivity of a crop and soil health.

Direct seeded rice needs higher nutrient requirement as compared to transplanted rice because of the higher plant density and greater production of biomass in the vegetative phase. Thus, direct seeded rice tend to develop nutrient deficiency at the reproductive stage of growth and senesce earlier. Application of external fertilizers along with incorporation of green manures ensures available more nutrients to rice crop and consequently resulted in higher yield [5]. All these factors affect not only the productivity of crop but also the nutrient uptake by the crop during growth and development. Therefore, a field experiment was conducted to study the effect of incorporation of tropical legumes on soil nutrient dynamics and its effect on succeeding crop rice.

\section{MATERIALS AND METHODS}

A field experiments were conducted during 2014 and 2015 on incorporation of tropical legumes in to soil and its effect on succeeding crop under paddy fallow at Agricultural Research Station, Dhadesugur, University of Agricultural Sciences, Raichur, Karnataka (India) situated at 15.6' N latitude and 76.8' E longitude with an altitude of $358 \mathrm{~m}$ above mean sea level. The soil of the experimental site was deep black and neutral in $\mathrm{pH}(8.04)$, EC $(0.47 \mathrm{ds} / \mathrm{m})$, medium in organic carbon content $(0.41 \%)$, low in soil available nitrogen (192 kg/ha), medium in phosphorus (58.5 kg/ha) and potassium (287.5 kg/ha). Experiment I: There are eight tropical legumes tested in this experiment and considered as eight treatments viz., $\mathrm{T}_{1}$ : Horsegram (Macrotyloma uniflorum), $\mathrm{T}_{2}$ : Cowpea (Vigna unguiculata), $\mathrm{T}_{3}$ : Fieldbean (Vicia faba), $\mathrm{T}_{4}$ : Clusterbean (Cyamopsis tetragonoloba), $\mathrm{T}_{5}$ : Diancha (Sesbania sp), $\mathrm{T}_{6}$ : Sunhemp (Crotalaria juncea), $\mathrm{T}_{7}$ : Pillepiesru (Vigna trilobata) and $\mathrm{T}_{8}$ : Blackgram (Vigna mungo) and replicated thrice. These tropical legumes were sown in month of May first week in both the years. Five 
plants were selected for the purpose of recording observations such as plant height and number leaves per plant in each treatment in each replication. Green biomass of tropical legumes was harvested in the month of July first week in both the years and recorded as net plot yield and converted in to yield per hectare and incorporated in soil with the same quantity in respective plots with tractor drawn rotovator. Experiment II: There are nine treatments viz., $\mathrm{T}_{1}$ : Incorporation of Horsegram (Macrotyloma uniflorum) + RDF (150:75:75 NPK kg/ha), $\mathrm{T}_{2}$ : Incorporation of Cowpea (Vigna unguiculata) + RDF, $\mathrm{T}_{3}$ : Incorporation of Fieldbean (Vicia faba) + RDF, $\mathrm{T}_{4}$ : Incorporation of Clusterbean (Cyamopsis tetragonoloba)+ RDF, $\mathrm{T}_{5}$ : Incorporation of Diancha (Sesbania $s p)+R D F$, $\mathrm{T}_{6}$ : Incorporation of Sunhemp (Crotalaria Juncea) + RDF, $\mathrm{T}_{7}$ : Incorporation of Pillepiesru (Vigna trilobata) $+\mathrm{RDF}$ and $\mathrm{T}_{8}$ : Incorporation of Blackgram (Vigna mungo) + RDF and $T_{9}$ : Control (Only RDF) and replicated thrice. The rice variety used was 'BPT-5204' of 150 days duration. The crop was sown in the $3^{\text {rd }}$ week of July in both the years. The recommended dose of fertilizer was applied as per the treatments. For observation, five plants were randomly selected in each plot of each replication and were tagged for the purpose of recording observations on growth parameters viz., plant height and number of productive tillers per hill at harvest. Yield parameter viz., number of filled grains per panicle. Similarly, paddy from each net plot in each replication was harvested and dried. The grains after threshing were weighed and recorded as grain yield per net plot. Further, this net plot grain yield was converted to grain yield per hectare and statistically analysed the data [6].

The plant samples were collected for recording dry matter production and estimation of nutrient concentration. The plant samples used for recording dry matter production at harvest were used for analyzing nutrients present in the plant. After recording the dry weight from each treatment the samples were powdered in a micro Willey mill. The samples were analyzed for concentration of different nutrients ( $\mathrm{N}, \mathrm{P}$ and $\mathrm{K}$ ) present in the plant parts. Nitrogen Phosphorus and potassium content of stover was estimated by modified micro-kjeldhal's method, Vanadomolybodo phosphoric acid yellow colour method and absorbance of the solution was recorded at $430 \mathrm{~nm}$ using spectrophotometer and flame photometer method, respectively [7]. Similarly, Available nitrogen was determined by alkaline permanganate method as outlined by [8].
Available phosphorus was determined by Bray's method as outlined by [7]. Available potassium was determined by neutral normal ammonium acetate solution using flame photometer as outlined by [7]. Balance of nitrogen, phosphorus and potassium were worked out by considering the respective total of initial soil available $\mathrm{N}, \mathrm{P}_{2} \mathrm{O}_{5}$ and $\mathrm{K}_{2} \mathrm{O}$. The $\mathrm{N}, \mathrm{P}_{2} \mathrm{O}_{5}$ and $\mathrm{K}_{2} \mathrm{O}$ were supplied through fertilizers (Urea, DAP and MOP, respectively) and manures (tropical legumes incorporation). The expected nutrient balance was arrived by subtracting $\mathrm{N}, \mathrm{P}_{2} \mathrm{O}_{5}$ and $\mathrm{K}_{2} \mathrm{O}$ uptake by the crop from the total soil $\mathrm{N}, \mathrm{P}_{2} \mathrm{O}_{5}$ and $\mathrm{K}_{2} \mathrm{O}$ [9].

\section{RESULTS AND DISCUSSION}

\subsection{Weather Condition during Crop Growth Period}

The meteorological data prevailed during the crop growth period and mean of 32 years was recorded at meteorological station located at experimental site are presented in Figs. 1 and 2. The total actual rainfall received during kharif2014 was $339.0 \mathrm{~mm}$ and 2015 was $655.6 \mathrm{~mm}$. It was almost good as compared to the average normal rainfall received over the last thirty years. The overall pest and disease incidence was least during this season.

\subsection{Growth and Green Biomass Yield of Tropical Legumes}

The mean data of 2014 and 2015 on growth parameters and green biomass yield of tropical leguminous plants is presented in Table 1 . Results revealed that, Taller plants $(80.2 \mathrm{~cm})$ having number of leaves per plant (20.0) and higher green biomass yield (5333 kg/ha) were recorded significantly in Diancha was grown under paddy fallow compared to other tropical legumes grown under paddy fallow. Whereas, blackgram was grown under paddy fallow recorded shorter plants $(54.2 \mathrm{~cm})$ and having less number of leaves per plant (5.80) led to lower green biomass yield (1533 kg/ha).

\subsection{Nutrient Concentration of Tropical Legumes at 60 DAS under Paddy Fallow}

Nutrient concentration of tropical leguminous plants is presented in Table 2. Results revealed that, Diancha plants contains significantly higher amount of nitrogen (3.5\%) and Phosphorus $(0.60 \%)$ followed by horse gram (3.52 and 
$0.14 \%$, respectively) and Pillepiesru (3.12 and $0.15 \%$, respectively). Further, Sunhemp plants contains significantly higher amount of potassium $(1.80 \%)$ followed by cluster bean $(1.62 \%)$ and field bean (1.32\%).

\subsection{Effect of Incorporation of Tropical Legumes on Soil Nutrient Dynamics}

The mean data of 2014 and 2015 on nutrient dynamics as influenced by the incorporation of tropical legumes in to soil at $15 \mathrm{DAl}$ is presented in Table 3. Results revealed that, Incorporation of diancha plants in soil significantly increases the organic carbon content $(0.51 \%)$, available nitrogen $(230.1 \mathrm{~kg} / \mathrm{ha})$, phosphorus $(64.2 \mathrm{~kg} / \mathrm{ha})$ and potassium (325.5 kg/ha) and which was onpar with the incorporation of sunhemp $(0.46 \%$, 228.4, 63.5 and $322.3 \mathrm{~kg} / \mathrm{ha}$, respectively), horsegram $(0.48 \%, 227.3,62.5$ and $320.9 \mathrm{~kg} / \mathrm{ha}$, respectively) and pillepiesru $(0.42 \%, 226.5$, 62.1 and $319.2 \mathrm{~kg} / \mathrm{ha}$, respectively). Further, incorporation of tropical legumes in soil increases the soil organic carbon content and available nutrients over to control plot where there is no incorporation of tropical legumes. Reports also showed that green manuring of leguminous plants viz., Diancha, Sunhemp etc., significantly increased available nitrogen, phosphorus and potassium levels in the soils [10] and [11].

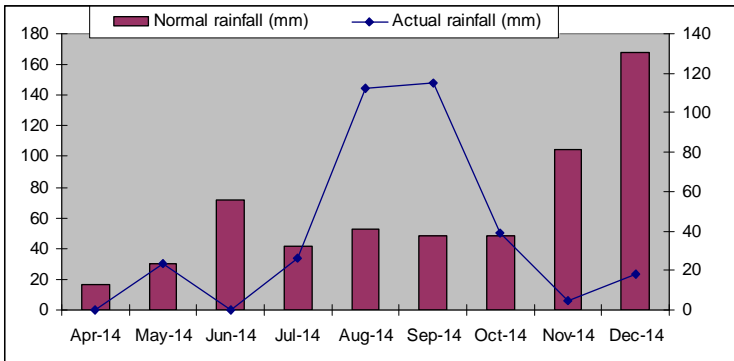

Fig. 1. Monthly rainfall $(\mathrm{mm})$ during Kharif 2014

\subsection{Effect of Incorporation of Tropical Legumes and Application of RDF on Growth and Yield of Succeeding Crop}

Growth and yield of direct seeded rice as influenced by the incorporation of tropical leguminous plants is presented in Table 4. Results revealed that, Incorporation of diancha plants in soil along with the application of recommended dose of fertilizer was significantly increases the plant height $(82.2 \mathrm{~cm})$, productive tillers per plant (236), filled grains per panicle (273) and grain yield (6069 kg/ha) and which was onpar with the incorporation of sunhemp in soil along with the application of recommended dose of fertilizer $(81.0 \mathrm{~cm}, 232,271$, and $5911 \mathrm{~kg} / \mathrm{ha}$, respectively), incorporation of horsegram in soil along with the application of recommended dose of fertilizer $(80.1 \mathrm{~cm}, 230,270$ and $5804 \mathrm{~kg} / \mathrm{ha}$, respectively) and incorporation of pillepiesru in soil along with the application of recommended dose of fertilizer $(79.1 \mathrm{~cm}, 228,269$ and 5786 $\mathrm{kg} / \mathrm{ha}$, respectively). Further, incorporation of tropical legumes in soil increases the growth and yield of direct seeded rice over to control plot where there is no incorporation of tropical legumes. Dhaincha, Sunhemp and Pillepiesru are popular green-manuring crop for rice and it is reported that rice grain yield was drastically in green manured treatments [10].

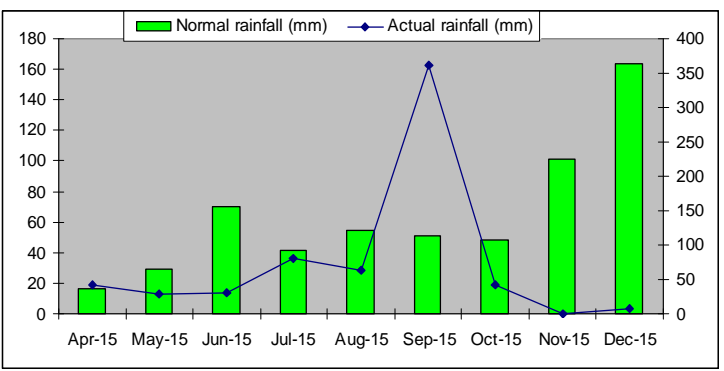

Fig. 2. Monthly rainfall (mm) during Kharif 2015

Table 1. Growth and biomass yield of tropical legumes at 60 DAS (Mean data of 2014 and 2015)

\begin{tabular}{llll}
\hline Treatments & Plant height $\mathbf{( c m )}$ & Number of leaves per plant & $\begin{array}{l}\text { Green biomass yield } \\
\text { (kg/ha) }\end{array}$ \\
\hline $\mathrm{T}_{1}:$ Horsegram & $60.5 \mathrm{~d}$ & $16.3 \mathrm{~b}$ & $4333 \mathrm{~b}$ \\
$\mathrm{~T}_{2}:$ Cowpea & $75.2 \mathrm{~b}$ & $15.0 \mathrm{C}$ & $4000 \mathrm{C}$ \\
$\mathrm{T}_{3}:$ Fieldbean & $76.2 \mathrm{~b}$ & $15.6 \mathrm{C}$ & $4167 \mathrm{c}$ \\
$\mathrm{T}_{4}:$ Clusterbean & $65.2 \mathrm{C}$ & $11.3 \mathrm{~d}$ & $3000 \mathrm{~d}$ \\
$\mathrm{~T}_{5}:$ Diancha & $80.2 \mathrm{a}$ & $20.0 \mathrm{a}$ & $5333 \mathrm{a}$ \\
$\mathrm{T}_{6}:$ Sunhemp & $81.5 \mathrm{a}$ & $16.6 \mathrm{~b}$ & $4433 \mathrm{~b}$ \\
$\mathrm{~T}_{7}:$ Pillepiesru & $60.2 \mathrm{~d}$ & $15.0 \mathrm{C}$ & $4200 \mathrm{~b}$ \\
$\mathrm{~T}_{8}:$ Blackgram & $54.2 \mathrm{e}$ & $5.80 \mathrm{e}$ & $1533 \mathrm{e}$ \\
\hline
\end{tabular}


Table 2. Nutrient concentration of tropical legumes at 60 DAS (Mean data of 2014 and 2015)

\begin{tabular}{llll}
\hline Treatments & Nitrogen (\%) & Phosphorus (\%) & Potassium (\%) \\
\hline $\mathrm{T}_{1}:$ :Horsegram & $3.52 \mathrm{a}$ & $0.14 \mathrm{c}$ & $1.12 \mathrm{c}$ \\
$\mathrm{T}_{2}:$ :owpea & $3.15 \mathrm{a}$ & $0.25 \mathrm{C}$ & $1.15 \mathrm{c}$ \\
$\mathrm{T}_{3}:$ Fieldbean & $3.12 \mathrm{a}$ & $0.21 \mathrm{C}$ & $1.32 \mathrm{~b}$ \\
$\mathrm{~T}_{4}$ :Clusterbean & $2.12 \mathrm{~b}$ & $0.41 \mathrm{~b}$ & $1.62 \mathrm{a}$ \\
$\mathrm{T}_{5}:$ Diancha & $3.50 \mathrm{a}$ & $0.60 \mathrm{a}$ & $1.20 \mathrm{~b}$ \\
$\mathrm{~T}_{6}:$ Sunhemp & $2.30 \mathrm{~b}$ & $0.50 \mathrm{a}$ & $1.80 \mathrm{a}$ \\
$\mathrm{T}_{7}:$ Pillepiesru & $3.12 \mathrm{a}$ & $0.15 \mathrm{C}$ & $1.25 \mathrm{~b}$ \\
$\mathrm{~T}_{8}:$ : & $2.10 \mathrm{~b}$ & $0.15 \mathrm{C}$ & $1.21 \mathrm{c}$ \\
\hline
\end{tabular}

Table 3. Soil pH, organic carbon and available N, P, K at 15 DAl of tropical legumes (Mean data of 2014 and 2015)

\begin{tabular}{|c|c|c|c|c|c|}
\hline Treatments & $\mathrm{pH}$ & O.C (\%) & $\begin{array}{l}\text { Nitrogen } \\
\text { (kg/ha) }\end{array}$ & $\begin{array}{l}\text { Phosphorus } \\
\text { (kg/ha) }\end{array}$ & $\begin{array}{l}\text { Potassium } \\
\text { (kg/ha) }\end{array}$ \\
\hline $\mathrm{T}_{1}:$ Horsegram & $7.12 \mathrm{a}$ & $0.48 \mathrm{a}$ & $227.3 \mathrm{a}$ & $62.5 \mathrm{a}$ & $320.9 \mathrm{a}$ \\
\hline $\mathrm{T}_{2}$ :Cowpea & $7.41 \mathrm{a}$ & $0.42 \mathrm{a}$ & $225.5 \mathrm{~b}$ & $61.5 \mathrm{a}$ & $315.8 \mathrm{~b}$ \\
\hline $\mathrm{T}_{3}:$ Fieldbean & $7.52 \mathrm{a}$ & $0.45 a$ & $224.9 \mathrm{~b}$ & $61.2 \mathrm{a}$ & $314.6 \mathrm{~b}$ \\
\hline $\mathrm{T}_{4}$ :Clusterbean & $7.62 \mathrm{~b}$ & $0.48 \mathrm{~b}$ & $215.8 \mathrm{c}$ & $60.2 \mathrm{~b}$ & $312.4 \mathrm{c}$ \\
\hline $\mathrm{T}_{5}:$ Diancha & $7.23 \mathrm{a}$ & $0.51 \mathrm{a}$ & $230.1 \mathrm{a}$ & $64.2 \mathrm{a}$ & $325.5 \mathrm{a}$ \\
\hline $\mathrm{T}_{6}:$ Sunhemp & $7.12 \mathrm{a}$ & $0.46 \mathrm{a}$ & $228.4 \mathrm{a}$ & $63.5 \mathrm{a}$ & $322.3 \mathrm{a}$ \\
\hline $\mathrm{T}_{7}$ :Pillepiesru & $7.58 \mathrm{a}$ & $0.42 \mathrm{a}$ & $226.5 \mathrm{a}$ & $62.1 \mathrm{a}$ & $319.2 \mathrm{a}$ \\
\hline $\mathrm{T}_{8}:$ Blackgram & $7.54 \mathrm{~b}$ & $0.42 \mathrm{~b}$ & $212.3 c$ & $60.1 \mathrm{~b}$ & $310.1 \mathrm{c}$ \\
\hline $\mathrm{T}_{9}:$ Control & $8.04 \mathrm{c}$ & $0.41 \mathrm{c}$ & $205.2 d$ & $58.5 \mathrm{~d}$ & $287.5 \mathrm{~d}$ \\
\hline
\end{tabular}

3.6 Effect of Incorporation of Tropical Leguminous Plants and Application of RDF on Uptake of DSR

The mean data pertaining to nitrogen, phosphorus and potassium uptake by direct seeded rice at harvest during 2014 and 2015 is presented in Tables 5-7. Nitrogen, phosphorus and potassium uptake by direct seeded rice varied due to varied levels of incorporation of tropical leguminous plants during both the years. Significantly higher uptake of nitrogen, phosphorus and potassium were recorded with the incorporation of diancha plants in soil along with the application of recommended dose of fertilizer (172.3, $\mathrm{kg} \mathrm{N}^{-1}, 32.1 \mathrm{~kg} \mathrm{P}_{2} \mathrm{O}_{5} \mathrm{ha}^{-1}$ and $274.2 \mathrm{~kg} \mathrm{~K}_{2} \mathrm{O} \mathrm{ha}{ }^{-1}$, respectively compared to other incorporation of leguminous plants in soil along with the application of recommended dose of fertilizer. The higher $\mathrm{N}, \mathrm{P}$ and $\mathrm{K}$ uptake by the crop during both the years was due to increase in grain and stover yield. It may be due to higher availability of nutrients by synergistic effect of incorporation of organic sources with inorganic fertilizers. [12] observed higher N, P and K uptake due to addition of leguminous plants in conjunction with Rhizobium. The Rhizobium produce photo-hormones which can stimulate root growth and induce changes in root morphology and increases the surface area as a result of root proliferation, which inturn could increase assimilation of nutrients. Significantly lower uptake of nitrogen, phosphorus and potassium were recorded in the treatment with the only application of recommended dose of fertilizer $\left(147.2 \mathrm{~kg} \mathrm{~N}^{-1}, 20.5 \mathrm{~kg} \mathrm{P}_{2} \mathrm{O}_{5} \mathrm{ha}^{-1}\right.$ and $255.1 \mathrm{~kg} \mathrm{~K}_{2} \mathrm{O} \mathrm{ha}^{-1}$, respectively) compared to other treatments. The lower N, P and K uptake during both the years was due to lower grain and stover yield may be due to lower availability of nutrients [13] and [14].

\subsection{Effect of Incorporation of Tropical Leguminous Plants and Application of RDF on Availability of Nutrients in Soil after Harvest of DSR}

Higher available nitrogen, phosphorus and potassium $\left(230.4 \mathrm{~kg} \mathrm{~N}^{-1}, 68.5 \mathrm{~kg} \mathrm{P}_{2} \mathrm{O}_{5} \mathrm{ha}^{-1}\right.$ and $318.2 \mathrm{~kg} \mathrm{~K}_{2} \mathrm{O} \mathrm{ha}^{-1}$, respectively) in soil after harvest of the crop was recorded with the only application of recommended dose of fertilizer. This might be owing to lower uptake of nitrogen, phosphorus and potassium. Whereas, lower available nitrogen, phosphorus and potassium $\left(207.5 \mathrm{~kg} \mathrm{~N} \mathrm{ha}^{-1}, 58.5 \mathrm{~kg} \mathrm{P}_{2} \mathrm{O}_{5} \mathrm{ha}^{-1}\right.$ and $300.2 \mathrm{~kg}$ $\mathrm{K}_{2} \mathrm{O}$ ha $^{-1}$, respectively) were recorded in soil after harvest of the crop in the treatment with the incorporation of diancha plants and application of recommended dose of fertilizer (Tables 5-7). 
Table 4. Effect of incorporation of tropical legumes and application of RDF on succeeding crop of DSR (Mean data of 2014 and 2015)

\begin{tabular}{|c|c|c|c|c|c|c|}
\hline Treatments & $\begin{array}{l}\text { Plant height } \\
\text { (cm) }\end{array}$ & $\begin{array}{l}\text { No. of productive } \\
\text { tillers } / \mathrm{m}^{2}\end{array}$ & $\begin{array}{l}\text { No. of filled } \\
\text { grains/panicle }\end{array}$ & $\begin{array}{l}\text { Grain yield } \\
\text { (kg/ha) }\end{array}$ & $\begin{array}{l}\text { Straw yield } \\
\text { (kg/ha) }\end{array}$ & $\begin{array}{l}\% \text { of increase } \\
\text { in grain yield }\end{array}$ \\
\hline $\mathrm{T}_{1}:$ Incorporation of Horsegram + RDF & $80.1 \mathrm{a}$ & $230 \mathrm{a}$ & $270 \mathrm{a}$ & $5804 \mathrm{a}$ & $7027 \mathrm{a}$ & $14.6 \mathrm{~b}$ \\
\hline $\mathrm{T}_{2}:$ Incorporation of Cowpea + RDF & $78.1 \mathrm{~b}$ & $224 \mathrm{~b}$ & $264 \mathrm{~b}$ & $5625 \mathrm{~b}$ & $6854 \mathrm{~b}$ & $11.1 \mathrm{c}$ \\
\hline $\mathrm{T}_{3}:$ Incorporation of Fieldbean +RDF & $76.7 \mathrm{~b}$ & 222 b & $263 \mathrm{~b}$ & $5521 \mathrm{~b}$ & 6788 b & $9.02 \mathrm{c}$ \\
\hline $\mathrm{T}_{4}:$ Incorporation of Clusterbean $+\mathrm{RDF}$ & $73.0 \mathrm{a}$ & $196 \mathrm{c}$ & $260 \mathrm{c}$ & $5398 \mathrm{c}$ & $6542 \mathrm{c}$ & $6.60 \mathrm{~d}$ \\
\hline $\mathrm{T}_{5}:$ Incorporation of Diancha $+\mathrm{RDF}$ & $82.2 \mathrm{a}$ & $236 \mathrm{a}$ & $273 a$ & 6069 a & $7270 \mathrm{a}$ & $19.8 \mathrm{a}$ \\
\hline $\mathrm{T}_{6}:$ Incorporation of Sunhemp +RDF & $81.0 \mathrm{a}$ & $232 \mathrm{a}$ & $271 \mathrm{a}$ & $5911 \mathrm{a}$ & 7185 a & $16.7 b$ \\
\hline $\mathrm{T}_{7}$ : Incorporation of Pillepiesru +RDF & $79.1 \mathrm{a}$ & $228 a$ & $269 a$ & 5786 a & $6911 \mathrm{a}$ & $14.3 \mathrm{~b}$ \\
\hline $\mathrm{T}_{8}$ : Incorporation of Blackgram +RDF & $72.0 \mathrm{c}$ & $184 \mathrm{c}$ & 262 c & $5277 \mathrm{c}$ & $6483 \mathrm{c}$ & $4.21 \mathrm{~d}$ \\
\hline $\mathrm{T}_{9}:$ Control (RDF) & $70.1 \mathrm{~d}$ & $180 \mathrm{~d}$ & $260 \mathrm{~d}$ & $5064 \mathrm{~d}$ & $6206 \mathrm{~d}$ & - \\
\hline
\end{tabular}

Table 5. Nitrogen balance in soil after harvest of DSR as influenced by the incorporation of tropical legumes and application of RDF (Mean data of 2014 and 2015)

\begin{tabular}{|c|c|c|c|c|c|c|c|}
\hline & $\begin{array}{l}\text { Initial soil } \\
\text { available } N \\
\left(\mathrm{~kg} \mathrm{ha}^{-1}\right)\end{array}$ & $\begin{array}{l}\text { Addition of } \mathrm{N} \\
\text { through fertilizer and } \\
\text { tropical legumes } \\
\left(\mathrm{kg} \mathrm{ha}^{-1}\right)\end{array}$ & $\begin{array}{l}\text { Total N } \\
\left(\text { kg ha }^{-1}\right)\end{array}$ & $\begin{array}{l}\text { Crop uptake } \\
\text { of } \mathrm{N} \\
\left(\mathrm{kg} \mathrm{ha}^{-1}\right)\end{array}$ & $\begin{array}{l}\text { Expected } \mathrm{N} \\
\text { balance } \\
\left(\mathrm{kg} \mathrm{ha}^{-1}\right)\end{array}$ & $\begin{array}{l}\text { Actual } \mathbf{N} \\
\text { balance } \\
\left(\mathrm{kg} \mathrm{ha}^{-1}\right)\end{array}$ & $\begin{array}{l}\text { Net loss (-) } \\
\left(\mathrm{kg} \mathrm{ha}^{-1}\right)\end{array}$ \\
\hline Treatment & (1) & (2) & $3=(1+2)$ & $(4)$ & $5=(3-4)$ & (6) & $7=(6-5)$ \\
\hline $\mathrm{T}_{1}:$ Incorporation of Horsegram + RDF & $227.3 \mathrm{a}$ & 302.5 & 529.8 & 165.2 & 364.6 & 211.8 & -152.8 \\
\hline $\mathrm{T}_{2}$ :Incorporation of Cowpea + RDF & $225.5 \mathrm{~b}$ & 290.8 & 516.3 & 163.2 & 353.1 & 215.3 & -137.8 \\
\hline $\mathrm{T}_{3}:$ Incorporation of Fieldbean +RDF & $224.9 \mathrm{~b}$ & 296.7 & 521.6 & 162.5 & 359.1 & 217.4 & -141.7 \\
\hline $\mathrm{T}_{4}$ :Incorporation of Clusterbean $+\mathrm{RDF}$ & $215.8 \mathrm{c}$ & 255.6 & 471.4 & 160.0 & 311.4 & 221.5 & -98.9 \\
\hline $\mathrm{T}_{5}$ :Incorporation of Diancha $+\mathrm{RDF}$ & $230.1 \mathrm{a}$ & 337.7 & 567.8 & 172.3 & 395.5 & 207.5 & -188 \\
\hline $\mathrm{T}_{6}:$ Incorporation of Sunhemp +RDF & $228.4 \mathrm{a}$ & 306.0 & 534.4 & 168.5 & 365.9 & 210.3 & -155.6 \\
\hline $\mathrm{T}_{7}$ : Incorporation of Pillepiesru +RDF & $226.5 \mathrm{a}$ & 297.8 & 524.3 & 164.2 & 360.1 & 214.5 & -145.6 \\
\hline $\mathrm{T}_{8}$ : Incorporation of Blackgram +RDF & $212.3 \mathrm{c}$ & 204.0 & 416.3 & 159.2 & 257.1 & 225.4 & -46.7 \\
\hline $\mathrm{T}_{9}:$ Control (RDF) & $205.2 d$ & 150 & 355.2 & 147.2 & 208.0 & 230.4 & -5.6 \\
\hline
\end{tabular}


Table 6. Phosphorus balance in soil after harvest of DSR as influenced by incorporation of tropical legumes and application of RDF (Mean data of 2014 and 2015)

\begin{tabular}{|c|c|c|c|c|c|c|c|}
\hline & $\begin{array}{l}\text { Initial soil } \\
\text { available } \mathrm{P}_{2} \mathrm{O}_{5} \\
\left(\mathrm{~kg} \mathrm{ha}^{-1}\right)\end{array}$ & $\begin{array}{l}\text { Addition of } \mathrm{P}_{2} \mathrm{O}_{5} \\
\text { through fertilizer } \\
\text { and manures } \\
\left(\mathrm{kg} \mathrm{ha}^{-1}\right)\end{array}$ & $\begin{array}{l}\text { Total } \\
\mathrm{P}_{2} \mathrm{O}_{5} \\
\left(\mathrm{~kg} \mathrm{ha}^{-1}\right)\end{array}$ & $\begin{array}{l}\text { Crop } \\
\text { uptake of } \\
\mathrm{P}_{2} \mathrm{O}_{5} \\
\left(\mathrm{~kg} \mathrm{ha}^{-1}\right)\end{array}$ & $\begin{array}{l}\text { Expected } \\
\mathrm{P}_{2} \mathrm{O}_{5} \\
\text { balance } \\
\left(\mathrm{kg} \mathrm{ha}^{-1}\right)\end{array}$ & $\begin{array}{l}\text { Actual } \\
\mathrm{P}_{2} \mathrm{O}_{5} \\
\text { balance } \\
\left(\mathrm{kg} \mathrm{ha}^{-1}\right)\end{array}$ & $\begin{array}{l}\text { Net loss (-)/ } \\
\text { Net gain }(+) \\
\left(\mathrm{kg} \mathrm{ha}^{-1}\right)\end{array}$ \\
\hline Treatment & (1) & (2) & $3=(1+2)$ & (4) & $5=(3-4)$ & (6) & $7=(6-5)$ \\
\hline $\mathrm{T}_{1}$ :Incorporation of Horsegram + RDF & $62.5 \mathrm{a}$ & 81.1 & 143.6 & 30.2 & 113.4 & 60.2 & -53.2 \\
\hline $\mathrm{T}_{2}:$ Incorporation of Cowpea + RDF & $61.5 \mathrm{a}$ & 80.6 & 142.1 & 27.1 & 115.0 & 62.5 & -52.5 \\
\hline $\mathrm{T}_{3}$ :Incorporation of Fieldbean +RDF & $61.2 \mathrm{a}$ & 80.8 & 142.0 & 25.3 & 116.7 & 63.5 & -53.2 \\
\hline $\mathrm{T}_{4}:$ Incorporation of Clusterbean $+\mathrm{RDF}$ & $60.2 \mathrm{~b}$ & 79.2 & 139.4 & 24.2 & 115.2 & 64.5 & -50.7 \\
\hline $\mathrm{T}_{5}$ :Incorporation of Diancha $+\mathrm{RDF}$ & $64.2 \mathrm{a}$ & 82.5 & 146.7 & 32.1 & 114.6 & 58.5 & -56.1 \\
\hline $\mathrm{T}_{6}:$ Incorporation of Sunhemp +RDF & $63.5 \mathrm{a}$ & 81.2 & 144.7 & 31.5 & 113.2 & 59.8 & -53.4 \\
\hline $\mathrm{T}_{7}$ : Incorporation of Pillepiesru +RDF & $62.1 \mathrm{a}$ & 80.9 & 143.0 & 28.2 & 114.8 & 61.5 & -53.3 \\
\hline $\mathrm{T}_{8}$ : Incorporation of Blackgram +RDF & $60.1 \mathrm{~b}$ & 77.1 & 137.2 & 22.1 & 115.1 & 65.8 & -49.3 \\
\hline $\mathrm{T}_{9}$ :Control (RDF) & $58.5 \mathrm{~d}$ & 75.0 & 133.5 & 20.5 & 113.0 & 68.5 & -44.5 \\
\hline
\end{tabular}

Table 7. Potassium balance in soil after harvest of DSR as influenced by incorporation of tropical legumes and application of RDF (Mean data of 2014 and 2015)

\begin{tabular}{|c|c|c|c|c|c|c|c|}
\hline & $\begin{array}{l}\text { Initial soil } \\
\text { available } \mathrm{K}_{2} \mathrm{O} \\
\left(\mathrm{kg} \mathrm{ha}^{-1}\right)\end{array}$ & $\begin{array}{l}\text { Addition of } \mathrm{K}_{2} \mathrm{O} \\
\text { through fertilizer } \\
\text { and manures } \\
\left(\mathrm{kg} \mathrm{ha}^{-1}\right)\end{array}$ & $\begin{array}{c}\text { Total } \mathrm{K}_{2} \mathrm{O} \\
\left(\mathrm{kg} \mathrm{ha}^{-1}\right)\end{array}$ & $\begin{array}{l}\text { Crop } \\
\text { uptake of } \\
\mathrm{K}_{2} \mathrm{O} \\
\left(\mathrm{kg} \mathrm{ha}^{-1}\right)\end{array}$ & $\begin{array}{l}\text { Expected } \\
\mathrm{K}_{2} \mathrm{O} \\
\text { balance } \\
\left(\mathrm{kg} \mathrm{ha}^{-1}\right)\end{array}$ & $\begin{array}{l}\text { Actual } \mathrm{K}_{2} \mathrm{O} \\
\text { balance } \\
\left(\mathrm{kg} \mathrm{ha}^{-1}\right)\end{array}$ & $\begin{array}{l}\text { Net gain } \\
(+) \\
\left(\mathrm{kg} \mathrm{ha}^{-1}\right)\end{array}$ \\
\hline Treatment & (1) & (2) & $3=(1+2)$ & $(4)$ & $5=(3-4)$ & $(6)$ & $7=(6-5)$ \\
\hline $\mathrm{T}_{1}$ :Incorporation of Horsegram + RDF & $320.9 \mathrm{a}$ & 123.5 & 444.4 & 270.1 & 174.3 & 305.4 & +131.1 \\
\hline $\mathrm{T}_{2}:$ Incorporation of Cowpea + RDF & $315.8 \mathrm{~b}$ & 119.8 & 435.6 & 266.3 & 169.3 & 308.5 & +139.2 \\
\hline $\mathrm{T}_{3}:$ Incorporation of Fieldbean +RDF & $314.6 \mathrm{~b}$ & 121.7 & 436.3 & 265.1 & 171.2 & 310.2 & +139.0 \\
\hline $\mathrm{T}_{4}$ :Incorporation of Clusterbean +RDF & $312.4 \mathrm{c}$ & 108.6 & 421.0 & 262.3 & 158.7 & 312.1 & +153.4 \\
\hline $\mathrm{T}_{5}:$ Incorporation of Diancha $+\mathrm{RDF}$ & $325.5 \mathrm{a}$ & 134.7 & 460.2 & 274.2 & 186.0 & 300.2 & +114.2 \\
\hline $\mathrm{T}_{6}:$ Incorporation of Sunhemp +RDF & $322.3 \mathrm{a}$ & 124.6 & 446.9 & 272.6 & 174.3 & 302.1 & +127.8 \\
\hline $\mathrm{T}_{7}$ : Incorporation of Pillepiesru +RDF & $319.2 \mathrm{a}$ & 122.0 & 441.2 & 268.5 & 172.7 & 307.2 & +134.5 \\
\hline $\mathrm{T}_{8}$ : Incorporation of Blackgram +RDF & $310.1 \mathrm{c}$ & 92.2 & 402.3 & 260.1 & 142.2 & 315.1 & +172.9 \\
\hline $\mathrm{T}_{9}$ :Control (RDF) & $287.5 \mathrm{~d}$ & 123.5 & 362.5 & 255.1 & 107.4 & 318.2 & +210.8 \\
\hline
\end{tabular}


This might be due to higher uptake of nitrogen, phosphorus and potassium as influenced by interactive behaviour of organic and inorganic sources of application, which increased the mobilization of nitrogen, phosphorus and potassium in the soil along with external supply of nitrogen, phosphorus and potassium through inorganic sources. Further, increased microbial activity in soil due to conjunctive use of organic sources along with inorganic fertilizer also would have contributed nitrogen, phosphorus and potassium to the available pool which ultimately reflected in the grain and straw yields. These results are in accordance with the studies of [15].

\subsection{Effect of Incorporation of Tropical Leguminous Plants and Application of RDF on Balance of Nitrogen, Phosphorus and Potassium in Soil after Harvest of DSR}

There was a negative balance of nitrogen observed in all the treatments during both the years. Incorporation of sunhemp plants along with the application of recommended dose of fertilizer recorded higher negative balance of nitrogen (155.6 kg ha-1) The negative balance of nitrogen after harvest of crop might be ascribed to the fact that loss of nitrogen. Similar results also reported by [16]. Similarly, negative balance of phosphorus observed in all the treatments. Incorporation of diancha plants along with the application of recommended dose of fertilizer recorded higher negative balance of phosphorus (56.1 $\mathrm{kg} \mathrm{P}_{2} \mathrm{O}_{5} \mathrm{ha}^{-1}$ ) This might be due to the fixation of available phosphorus in soils ultimately resulted in net loss of available phosphorus. These results are onpar with the findings of [16]. However, positive balance of potassium was observed in all the treatments. Application of only recommended dose of fertilizer recorded higher positive balance of potassium (210.8 $\mathrm{kg} \mathrm{K}_{2} \mathrm{O} \mathrm{ha}^{-1}$ ). The higher positive balance in potassium was probably due to high potassium available in soil. This might be due to the fact that the fixed potassium might have been made available by the rice and enriched the soil, resulting in a positive balance of potassium observed in this treatment, which is unique in nature (Tables 5 to 7 ).

\section{CONCLUSION}

From this study, we would like to conclude that, Incorporation of tropical leguminous plants viz., Diancha, Sunhemp, Pille piesru etc., in to soil under paddy fallow increases the soil organic carbon content and available nitrogen, phosphorus and potassium. Further, growing of rice by direct sown as succeeding crop under this soil increases the grain yield of rice.

\section{COMPETING INTERESTS}

Authors have declared that no competing interests exist.

\section{REFERENCES}

1. Nguyen VN. Rice production, consumption and nutrition. FAO STAT; 2002.

2. Walia US, Walia MK. Scope of direct seeded rice in India. Proc. Biennial Conference, ISWSon New and Emerging Issues in Weed Science. HAU, Hissar, India. 2007;20.

3. Dhyani VC, Singh VP and Singh G. Response of rice to crop establishment and weed management. Indian J. Weed Sci. 2005;37:260-262.

4. Nageshwari R, Subhramaniayan B. Influence of delayed basal dressing and split application of nitrogen in wet-seeded rice (Oryza sativa L.). Indian J. Agron. 200449:40-42.

5. Kumar J, Singh D, Puniya R and Pandey PC. Effect of weed management practices on nutrient uptake by direct seeded rice. Oryza. 2010;47:291-94.

6. Gomez KA, Gomez AA. Statistical procedures for agricultural research (2 ed.). John wiley and sons, New York. 1984;680.

7. Jackson ML. Soil chemical analysis. Prentice Hall of India Pvt. Ltd., New Delhi. 1967;183-192.

8. Subbiah BV, Asija CL. A rapid procedure for estimation of available nitrogen in soils. Curr. Sci. 1959;25:259-260.

9. Mongia AD, Gangwar B. Nutrient balance under multiple cropping sequence in an acid soil (Typic Tropofluvents). Indian J. Agron. 1991;36(1):17-22.

10. Gurung GB, Sherchan DP. Green manuring effect of Dhaincha (Sesbania aculeate Pers) on rice in the farmer's field. PAC Working Paper No. 192. PAC, Dhankuta. 1997;8.

11. Mathukia RK, Ponkia HP, Polara AM. In situ moisture conservation and zinc fertilization for rainfed pigeonpea (Cajanus cajan L.). The Bioscan. 2016; 11(1):247-250. 
12. Krishnamoorthy T. Studies on integrated nutrient management in kharif sorghum (Sorghum bicolor (L.) Moench) in transition tract. M.Sc. (Agri.) Thesis, University of Agricultural Sciences, Dharwad; 1995.

13. Negalur RB. Response of kharif pop sorghum genotypes to FYM and mineral fertilizer in black soil under rainfed conditions. M.Sc. (Agri) Thesis, University of Agricultural Sciences, Dharwad; 2000.

14. Nagar RK, Goud VV, Rajesh Kumar, Ravindra Kumar. Effect of incorporation of FYM, pigeonpea stalk, phosphocompost on growth, yield and nutrient uptake in pigeonpea based intercropping system. The Bioscan. 2015;10(3):339343.

15. Gajanana GN, Shankar MA, Somashekar K, Krishnappa AM. Importance of plant nutrient management in dryland agriculture Bulletin. AICRP on Dryland Agriculture, UAS, Bangalore. 2000;1-38.

16. Yin-Po Wang, Cben Ching Chao. The effect of organic farming practices on the chemical, physical and biological properties of soil in Taiwan. FFTC book series No. 1995;46:33-39.

(0) 2017 Ramesha et al.; This is an Open Access article distributed under the terms of the Creative Commons Attribution License (http://creativecommons.org/licenses/by/4.0), which permits unrestricted use, distribution, and reproduction in any medium, provided the original work is properly cited. 